\title{
Metabolic risk factors clustering among adolescents: a comparison between sex, age and socioeconomic status
}

\author{
Agregação de fatores de risco metabólico em adolescentes: \\ uma comparação entre sexo, idade e nível socioeconômico
}

\author{
Roseane de Fátima Guimarães ${ }^{1}$ \\ Michael Pereira da Silva ${ }^{2}$ \\ Oldemar Mazzardo ${ }^{3}$ \\ Rafael Vieira Martins ${ }^{4}$ \\ Priscila Iumi Watanabe ${ }^{4}$ \\ Wagner de Campos ${ }^{4}$
}

\footnotetext{
${ }^{1}$ École de kinésiologie et des sciences de l'activité physique de la Faculté de médecine,Université de Montréal. 2900 Edouard Montpetit Blvd, QC H3T 1J4. Montréal QC Canada. roseanefguimaraes@ gmail.com

${ }^{2}$ Departamento de Educação Física, Universidade Estadual do Centro-Oeste do Paraná (Unicentro). Guarapuava PR Brasil. ${ }^{3}$ Departamento de Educação Física, Unicentro. Mal. Cândido Rondon PR Brasil.

${ }^{4}$ Departamento de

Educação Física,

Universidade Federal do

Paraná. Curitiba PR Brasil.
}

\begin{abstract}
The aim was to compare the metabolic risk factors (MRF) between sex, age and socioeconomic status in a sample of adolescents from $\mathrm{Cu}$ ritiba, Brazil. A cross-sectional school-based study was conducted on 997 adolescents (429 boys) aged 12-17 years old from public schools. Total Cholesterol (TC), LDL-c, HDL-c, Triglycerides, Glycemia, Blood Pressure, waist circumference and body mass index were measured. Sex, age and socioeconomic status information was obtained using a questionnaire. Descriptive analyses, Fisher Exact and Chi-Square Tests were used to establish the sample's characteristics and the MRF comparison between variables. We found that $27.4 \%$ were classified as overweight/obese, almost half of them had TC and LDL-c classified as limitrophe/ altered, with a difference between the sexes ( $p<$ 0.01 ), and that a higher percentage of altered values was seen among girls. The percentage of 3 and 4 or more MRF was $13.8 \%$ and $6.3 \%$, respectively. In addition, $86.5 \%$ of the participants had at least one and $39.7 \%$ had at least two MRF. We conclude that there was a high percentage of overweight/obese, as well as a great number of subjects with altered TC and HDL-c. We also pointed out the large percentage of aggregated metabolic risk factors in both sexes. Strategies to reduce metabolic risk factors are required.
\end{abstract}

Key words Risk factors, Sex, Age, Social class and adolescent
Resumo O objetivo do estudo foi comparar os fatores de risco metabólicos (FRM) entre sexo, idade e nivel socioeconômico numa amostra de adolescentes de Curitiba, Brasil. O estudo transversal foi conduzido com 997 adolescentes da rede pública de ensino (429 meninos) com idade entre 12-17 anos. Coletaram-se dados de colesterol total (CT), LDL-c, HDL-c, triglicerídeos, glicemia, pressão arterial, circunferência de cintura e indice de massa corporal. Informações sobre sexo, idade e nivel socioeconômico foram coletados por meio de um questionário. Foram utilizadas análises descritivas, teste exato de Fisher e Qui-quadrado. Observou-se que 27,4\% foram classificados como sobrepeso/obeso, quase metade com CT e LDL-c limitrofes/alterados, com uma diferença entre os sexos $(p<0,01)$ e uma proporção maior entre as meninas. Verificou-se que as proporções de 3 e 4 ou mais FRM foram 13,8\% e 6,3\%, respectivamente. Adicionalmente, $86,5 \%$ e 39,7\% dos adolescentes demonstraram ao menos um e dois FRM, respectivamente. Conclui-se que houve um elevado percentual de sobrepeso/obeso, assim como um grande número de sujeitos com CT e HDL-s alterados. Verificou-se um grande percentual de agregação de FRM em ambos os sexos. São necessárias estratégias para reduzir esses fatores de risco nessa fase da vida.

Palavras-chave Fatores de risco, Sexo, Idade, Nível socioeconômico e adolescente 


\section{Introduction}

Adolescence is an important period for the development and adoption of healthy behaviors which may be maintained throughout adult life ${ }^{1}$. Elevated waist circumference (WC) and body mass index (BMI) are independent risk factors for coronary heart disease and diabetes, because of its relation to dyslipidemia, hyperinsulinemia and hypertension ${ }^{2}$. The development of these metabolic risk factors at this stage appears to increase the risk of chronic obesity and its complications later in life ${ }^{1}$. Therefore, the monitoring of health-related risk factors should get more attention from public health professionals.

Different studies have demonstrated that health-related risk factors are associated with conditions for the development of chronic non-communicable diseases in children and adolescents $^{2-6}$. In addition, the increase of metabolic disorders such as hypertension, hyperglycemia, elevated serum triglyceride and total cholesterol, and decreased high-density lipoprotein with abdominal adiposity, can lead to metabolic syndrome $^{7}$. Studying the aggregation of metabolic risk factors is important to identify and prevent the development of cardiovascular diseases in adolescents.

Despite the considerable amount of literature examining risk factors in Brazilian adolescents $^{2,8,9}$, studies investigating the sex, age and socioeconomic status (SES) disparities in the proportions of health related risk factors are rare. However, the understanding of these differences is of the utmost importance to develop preventive intervention programs for adolescents.

The present study aimed to compare metabolic risk factors between sex, age and socioeconomic status in a sample of adolescents.

\section{Methods}

\section{Sampling procedures}

This is a cross-sectional study with 997 adolescents of both sexes (429 boys) intentionally selected from 13 public schools in the city of $\mathrm{Cu}-$ ritiba in southern Brazil. The data collection took place on the premises of the schools during the school hours of the selected subjects, in the presence of the researcher in charge and duly trained collaborators.

\section{Ethical considerations}

The methodological procedures adopted were approved by the Federal University of Paraná's Ethics Committee on Research. All the adolescents were granted previous authorization by parents/caretakers to voluntarily take part in the study.

\section{Blood pressure}

Blood pressure (BP) was measured by trained technicians before the blood sampling procedure. The BP measurement was performed in accordance with the method described in The Fourth Report on the Diagnosis, Evaluation, and Treatment of High Blood Pressure in Children and Adolescents ${ }^{10}$. The students were asked to rest in the sitting position for 5-10 minutes prior to the BP assessment. The systolic blood pressure and the diastolic blood pressure were measured on the right arm using a sphygmomanometer of mercury column. Two measurements were taken after 5 and 10 minutes of rest, respectively. The mean of the two measurements was the value taken into consideration. If the two measurements differed by $>2 \mathrm{mmHg}$, a third measurement was performed. According to percentiles of blood pressure based on height, gender and age the participants were classified as normotensive $\left(<85^{\text {th }}\right.$ Percentile), prehypertensive $\left(\geq 85^{\text {th }}\right.$ Percentile and $<95^{\text {th }}$ Percentile), or hypertensive ( $\geq$ $95^{\text {th }}$ Percentile). To avoid misclassification, a second measurement was taken on the next day for those who had been classified as prehypertensive or hypertensive.

\section{Biochemical tests}

The blood samples were collected in the morning after at least 12 hours' fasting (only water was allowed). The drawing of the blood samples was performed by a nurse from a laboratory hired specifically for this purpose. For each subject approximately $8 \mathrm{ml}$ of blood was drawn and immediately stored in a thermos container for transport.

The automated enzymatic colorimetric method was used to measure total cholesterol (TC), high density lipoprotein (HDL-c), and triglycerides (TG), whereas low density lipoprotein (LDL-c) was calculated using Friedewald et al.'s formula (LDL-c $=$ TC-HDL $-\mathrm{TG} / 5)^{11}$. The participants' glucose profiles were also obtained through the analysis of their glucose levels using 
the Automated Humanstar80 method. Based on these results, the subjects' metabolic profiles were determined.

The classification of the metabolic profiles followed the reference values proposed for children and adolescents in the First Childhood and Adolescence Atherosclerosis Prevention Directive classifying the adolescents into the Normal, Limitrophe and Elevated categories ${ }^{12}$. Due to the small number of adolescents with altered fasting glucose levels, the Limitrophe and Elevated categories were combined into a category named Altered.

\section{Anthropometric measures}

Height and weight were measured to determine Body Mass Index $(\mathrm{BMI})^{13}$. Classification of BMI status followed the reference tables for adolescents proposed by the World Health Organization for each sex and age ${ }^{14}$. The waist-circumference (WC) was measured twice, using a flexible metal tape measure (WISO) with a 0.1 $\mathrm{cm}$ scale, at the mid-point between the iliac crest and last $\mathrm{rib}^{13}$, and the classification used the cutoff points of Freedman et al. ${ }^{15}$.

\section{Aggregation of Metabolic risk factors}

Aggregation of Metabolic risk factors was defined as the simultaneous presence of two or more alterations in the eight metabolic and obesity markers measured during data collection. Five categories were created according to the number of simultaneous alterations observed (no MRF; 1 MRF; 2 MRF; 3 MRF; and 4 or more MRF).

The alterations were defined as: a) Biochemical variables: Adolescents who presented lower concentration of HDL-c and elevated values of
Glycemia, TC, LDL-c, TG; b) Blood Pressure: Adolescents classified as hypertensive; c) BMI: Adolescents classified as overweight or obese; and d) Waist circumference: Adolescents classified as Elevated Waist circumference.

\section{Socioeconomic status questionnaire}

The socioeconomic status (SES) was defined using the Brazilian Association of Research Companies' questionnaire ${ }^{16}$, which determines socioeconomic classes based upon the ownership of appliances at home, specific goods and the head of the household educational level. Originally the SES is divided in five categories (A, B, C, D and E) however, due to the fact that there were few individuals in lower SES categories (C, D and E); the adolescents were grouped into three categories: $\mathrm{A}, \mathrm{B}$, and $\mathrm{C} / \mathrm{D} / \mathrm{E}$.

\section{Statistical analysis}

Descriptive analysis (mean and relative frequency) was used to identify the sample's characteristics. The Fisher Exact Test and the Chisquare test were used to identify differences in metabolic risk factors across age, sex and SES adopting $\mathrm{p}<0.05$ as a significance level.

\section{Results}

The Table 1 describes the demographic characteristics of the participants. There was a predominance of females (57\%), between 14 and 16 years old (49.2\%), mostly classified as B SES (63.9\%).

Table 2 shows the percentage of anthropometric data and metabolic values of the study's participants, for both sexes, different age groups and SES classifications.

Table 1. Demographic characteristics of participants.

\begin{tabular}{lccc}
\hline & Overall $(\mathbf{N}=\mathbf{9 9 7})$ & Boys $(\mathbf{N}=\mathbf{4 2 9})$ & Girls $(\mathbf{N}=\mathbf{5 6 8})$ \\
\hline \multicolumn{1}{c}{ Age $($ Mean \pm SD) } & $\mathbf{1 5 . 4 \pm 1 . 4}$ & $\mathbf{1 5 . 5} \pm \mathbf{1 . 4}$ & $\mathbf{1 5 . 4 \pm 1 . 4}$ \\
\hline Age Groups & $\mathbf{N}(\%)$ & $\mathbf{N}(\%)$ & $\mathbf{N}(\mathbf{\%})$ \\
12-14 years & $364(36.5 \%)$ & $146(34.0 \%)$ & $219(38.5 \%)$ \\
14-16 years & $491(49.2 \%)$ & $218(50.8 \%)$ & $272(47.9 \%)$ \\
16-18 years & $142(14.3 \%)$ & $65(15.2 \%)$ & $77(13.6 \%)$ \\
Socioeconomic Status & $\mathbf{N}(\%)$ & $\mathbf{N}(\%)$ & $\mathbf{N}(\%)$ \\
A & $60(6.0 \%)$ & $28(6.5 \%)$ & $32(5.6 \%)$ \\
B & $637(63.9 \%)$ & $290(67.6 \%)$ & $347(61.1 \%)$ \\
C/D/E & $300(30.1 \%)$ & $111(25.9 \%)$ & $189(33.3 \%)$ \\
\hline
\end{tabular}


Table 2. Metabolic risk factors by sex, age and SES.

\begin{tabular}{|c|c|c|c|c|c|c|c|c|c|c|c|c|}
\hline & \multirow[b]{2}{*}{ Total } & \multicolumn{2}{|c|}{ Sex } & \multicolumn{5}{|c|}{ Age } & \multicolumn{4}{|c|}{ Socioeconomic Status } \\
\hline & & Boys & Girls & $\mathrm{p}$ & $\begin{array}{c}12 \text { to } 14 \\
\text { years }\end{array}$ & $\begin{array}{c}14 \text { to } 16 \\
\text { years }\end{array}$ & $\begin{array}{c}16 \text { to } 18 \\
\text { years }\end{array}$ & $\mathrm{p}$ & A & B & $\mathrm{C} / \mathrm{D} / \mathrm{E}$ & $\mathrm{p}$ \\
\hline BMI & & $\%$ & & & & $\%$ & & & & $\%$ & & \\
\hline Severe Thinness & .3 & .7 & 0 & & .6 & .2 & 0 & & 1.7 & .3 & 0 & \\
\hline Thinness & 1.4 & 1.9 & 1.1 & & 1.7 & 1.0 & 2.1 & & 1.7 & 1.1 & 2.0 & \\
\hline Eutrofic & 70.9 & 68.2 & 73.0 & .11 & $63.7^{\mathrm{ab}}$ & $74.4^{\mathrm{a}}$ & $77.1^{\mathrm{b}}$ & .01 & 63.3 & 72.7 & 68.7 & .38 \\
\hline Overweight & 19.0 & 21.0 & 17.5 & & 22.2 & 17.6 & 15.7 & & 23.3 & 18.0 & 20.4 & \\
\hline Obese & 8.4 & 8.2 & 8.5 & & $11.9^{\mathrm{ab}}$ & $6.7^{\mathrm{a}}$ & $5.0^{\mathrm{b}}$ & & 10.0 & 8.0 & 8.8 & \\
\hline WC & & $\%$ & & & & $\%$ & & & & $\%$ & & \\
\hline Normal & 83.3 & 85.1 & 82.4 & 28 & 81.6 & 85.4 & 82.4 & 23 & 83.3 & 84.4 & 82.0 & 00 \\
\hline Altered & 16.7 & 14.9 & 17.6 & .2 & 18.4 & 14.6 & 17.6 & & 16.7 & 15.6 & 18.0 & .09 \\
\hline $\mathrm{BP} \mathrm{mmHg}$ & & $\%$ & & & & $\%$ & & & & $\%$ & & \\
\hline Normal & 84.4 & $80.8^{\mathrm{a}}$ & $87.8^{\mathrm{a}}$ & & 83.7 & 84.8 & 87.9 & & 75.0 & 85.8 & 84.7 & \\
\hline Prehypertension & 13.0 & $15.2^{\mathrm{a}}$ & $10.6^{\mathrm{a}}$ & .00 & 14.4 & 12.4 & 8.5 & .37 & 20.0 & 12.3 & 11.5 & .10 \\
\hline Hypertension & 2.6 & $4.0^{\mathrm{a}}$ & $1.6^{\mathrm{a}}$ & & 1.9 & 2.8 & 3.5 & & 5.0 & 1.9 & 3.7 & \\
\hline Glycemia mg/dL & & $\%$ & & & & $\%$ & & & & $\%$ & & \\
\hline$<100$ & 99.1 & 98.6 & 99.5 & & 98.9 & 99.6 & 97.9 & & 100.0 & 98.8 & 99.7 & \\
\hline $100-125$ & .9 & 1.4 & .5 & .15 & 1.1 & .4 & 2.1 & .15 & 0 & 1.2 & .3 & .29 \\
\hline$\geq 126$ & 0 & 0 & 0 & & 0 & 0 & 0 & & 0 & 0 & 0 & \\
\hline TG mg/dL & & $\%$ & & & & $\%$ & & & & $\%$ & & \\
\hline$<100$ & 89.9 & 90.0 & 89.8 & & 90.6 & 89.3 & 90.1 & & 85.0 & 90.5 & 89.7 & \\
\hline $100-129$ & 7.1 & 7.0 & 7.2 & .99 & 6.9 & 7.5 & 6.3 & .93 & 11.7 & 6.6 & 7.3 & .69 \\
\hline$\geq 130$ & 3.0 & 3.0 & 3.0 & & 2.5 & 3.2 & 3.6 & & 3.3 & 3.0 & 30 & \\
\hline $\mathrm{TC} \mathrm{mg} / \mathrm{dL}$ & & $\%$ & & & & $\%$ & & & & $\%$ & & \\
\hline$<150$ & 49.1 & $55.9^{\mathrm{a}}$ & $43.8^{\mathrm{a}}$ & & $56.6^{\mathrm{a}, \mathrm{b}}$ & $46.0^{\mathrm{a}}$ & $40.8^{\mathrm{b}}$ & & 43.4 & 50.8 & 46.7 & \\
\hline $150-169$ & 25.2 & 23.3 & 26.6 & .00 & 23.9 & 25 & 27.5 & .00 & 28.3 & 23.6 & 28.0 & .54 \\
\hline$\geq 170$ & 25.7 & $20.7^{\mathrm{a}}$ & $29.6^{\mathrm{a}}$ & & $19.5^{\mathrm{a}, \mathrm{b}}$ & $28.5^{\mathrm{a}}$ & $31.7^{\mathrm{b}}$ & & 28.3 & 25.6 & 25.3 & \\
\hline LDL-c mg/dL & & $\%$ & & & & $\%$ & & & & $\%$ & & \\
\hline$<100$ & 55.5 & $61.5^{\mathrm{a}}$ & $50.9^{\mathrm{a}}$ & & 58.3 & 55.3 & 49.3 & & 50.0 & 56.1 & 55.3 & \\
\hline $100-129$ & 31.3 & $25.4^{\mathrm{a}}$ & $35.7^{\mathrm{a}}$ & .00 & 27.7 & 33.4 & 33.1 & .12 & 38.3 & 31.2 & 30.0 & .69 \\
\hline$\geq 130$ & 13.2 & 13.1 & 13.4 & & 14.0 & 11.3 & 17.6 & & 11.7 & 12.7 & 14.7 & \\
\hline HDL-c mg/dL & & $\%$ & & & & $\%$ & & & & $\%$ & & \\
\hline$\geq 45$ & 33.0 & 29.8 & 35.6 & 06 & 33.8 & 31.2 & 37.3 & 36 & 31.7 & 33.0 & 33.3 & 97 \\
\hline$<45$ & 67.0 & 70.2 & 64.4 & .00 & 66.2 & 68.8 & 62.7 & .00 & 68.3 & 67.0 & 66.7 & .91 \\
\hline Clustering of MRF & & $\%$ & & & & $\%$ & & & & $\%$ & & \\
\hline None & 13.5 & 13.8 & 13.4 & & 11.9 & 14.0 & 16.3 & & 10.0 & 12.2 & 17.5 & \\
\hline $1 \mathrm{MRF}$ & 46.7 & 48.0 & 45.8 & & 47.0 & 47.6 & 43.3 & & $46.7^{\mathrm{a}}$ & $50.6^{\mathrm{b}}$ & $38.4^{\mathrm{a}, \mathrm{b}}$ & \\
\hline $2 \mathrm{MRF}$ & 19.6 & 17.9 & 20.8 & .49 & 21.0 & 19.0 & 17.7 & .90 & 18.3 & 17.7 & 23.9 & .03 \\
\hline $3 \mathrm{MRF}$ & 13.8 & 12.8 & 14.6 & & 13.5 & 13.6 & 15.6 & & 20.0 & 13.4 & 13.5 & \\
\hline 4 or more MRF & 6.3 & 7.5 & 5.5 & & 6.6 & 5.9 & 7.1 & & 5.0 & 6.1 & 7.1 & \\
\hline
\end{tabular}

SES= Social Economic Status; BMI $=$ Body Mass Index; WC $=$ Waist-circumference; $\mathrm{BP}=$ Blood pressure TC $=$ Total Cholesterol; LDL-c $=$ low density lipoprotein; HDL-c= high density lipoprotein; TG= triglyceride; MRF= Metabolic Risk Factor. Sex, Age and SES differences calculated by Fisher's exact. Equal superscript letters denote statistically significant differences between groups at $\mathrm{p}<0.05$.

Significant differences were found between age groups in the eutrophic classification, and also between BP, TC and LDL-c between sex, as well as TC between age groups. No significant difference was observed between the metabolic variables and SES. Regarding the aggregated metabolic risk factors, the percentage of 3 and 4 or more MRF was $13.8 \%$ and $6.3 \%$, respectively. In addition, $86.5 \%$ of the participants had at least one and $39.7 \%$ had at least two MRF. The presence of one MRF was significant different between SES. 


\section{Discussion}

The results of this study showed that $27.4 \%$ of the adolescents were classified as overweight and obese. In studies conducted in the southern part of Brazil, we observe prevalences similar to our findings, as reported by Niehues et al. ${ }^{17}$ in their systematic review (25.7\% overweight and obese adolescents). The prevalence of overweight and obesity is rising in children and adolescents in developing countries, increasing from $8.1 \%$ (7.78.6) in 1980 to $12.9 \%$ (12.3-13.5) in 2013 for boys, and from $8.4 \%(8.1-8.8)$ to $13.4 \%(13.0-13.9)$ for $\operatorname{girls}{ }^{18}$.

The decline in the percentage of overweight and obesity as the age increases may have occurred due to the maturation process, since adolescents grow at faster rates during puberty, rapidly changing height and weight ${ }^{19}$. In addition to the maturational factor, teenagers are more likely to be influenced by socio-cultural issues, especially girls, which are often encouraged to adopt weight reduction behaviors, such as exercising and dieting, trying to meet the aesthetic standards of society.

Regarding WC, our sample showed a smaller percentage of altered WC (Overall: 16.7\%; Boys: 14.9\%; Girls: $17.6 \%$ ) when compared to a previous study carried out with adolescents from the same part of the country, where $28.4 \%$ of the boys and $36.3 \%$ of the girls had altered $\mathrm{WC}^{20}$. Nevertheless, WC is a key parameter of the metabolic syndrome and it is known that children who have one risk factor are likely to have others as well, especially if they are overweight $t^{21}$.

In the present study, higher percentages of altered BP were found among boys. This data reinforces that there is evidence that androgens, such as testosterone, are one of the mechanisms responsible for the gender differences in blood pressure $^{22}$. In agreement with our findings, a previous study identified in pubertal males higher blood pressure values than shown in age-matched females $^{22}$. These results demonstrate that in adolescence and puberty, when androgen levels are increasing, blood pressure is higher in boys than in girls, but these analysis should take into account the maturational status, given the gender differences during adolescence. Additionally, the adolescence is a period of development characterized by excess of sedentary behavior, physical inactivity and bad eating habits. These risk factors generate an additional risk of high blood pressure in adolescents?.

Concerning metabolic variables, there were differences between sexes in high levels of TC
$(>170 \mathrm{mg} / \mathrm{dl})$ and limitrophe LDL-C (100-129 $\mathrm{mg} / \mathrm{dl}$ ), with girls showing higher prevalences at both risk factors. The hormonal status in this age could have some influence in these results due to the fact that the larger production of estrogen, which occurs in the female system in this period, can contribute temporarily to higher serum concentration of TC and its fraction $s^{23}$.

In addition, the percentage in the elevated TC classification increased with age, from 12 to 18 years old. This result corroborates, in part, the outcomes of the longitudinal study by Frohnert et al. ${ }^{24}$, where the lipid variables, including total cholesterol, LDL, HDL, and triglycerides, were significantly higher in older adolescents. However, the literature regarding serum lipid changes during adolescence is not clearly elucidated, as shown by the dissimilar results obtained by Courtney and $\operatorname{Ian}^{25}$ with 6067 adolescents. They described that TC concentrations declined during early adolescence and rose thereafter, approaching adult concentrations. Moreover, the findings of Dai et al. ${ }^{26}$ demonstrated that TC decreased by $\sim 19 \mathrm{mg} / \mathrm{dL}$ from ages 9 to 16 years in girls and more steeply from ages 10 to 17 years in boys.

The aggregation of metabolic risk factors contribute importantly to worldwide adult mortality and its occurrence during adolescence has been reported by several studies ${ }^{27}$. The results of this study showed that $13.5 \%$ of the adolescents presented zero metabolic risk factors, while $46.7 \%$, $19.6 \%$ and $13.8 \%$ had one, two and three aggregated risk factors, respectively. As for sex differences, girls presented greater percentages of three aggregated MRF than boys. As for the SES, the difference found in one MRF between $A$ and $C / D / E$ classification and also between $B$ and $C / D / E$, was discussed in Moraes and Falcão ${ }^{20}$ study, which showed that the prevalence of MRF has increased in the middle-income brackets, contributing to increased inequalities in health, however it was different from Nunes et al..$^{28}$ study, were they found a significant association between some risk behaviors and lower socioeconomic status.

The Bogalusa Autopsy study conducted by Berenson and Srnivasan ${ }^{29}$, with subjects aged 2-39 years, found that the presence of multiple risk factors (BMI, high blood pressure, TG, LDL-c, HDL-c, TC) in individuals over an extended period of time creates a lifetime burden associated with underlying cardiovascular disease. The relation between risk factors and cardiovascular change is evident for both atherosclerosis and hypertension. These outcomes 
reinforce the recommendation that public health organizations/governments should direct special attention to the prevention of these risk factors in early life.

The Expert Panel on Integrated Guidelines for Cardiovascular Health and Risk Reduction in Children and Adolescents suggests that early identification and control of dyslipidemia and obesity throughout youth would substantially reduce the risk of clinical cardiovascular disease beginning in young adult life ${ }^{30}$.

The limitations of this study need to be pointed out. First, a non-probabilistic method (convenience sampling) was used in the study. Second, the cross-sectional design does not provide support to establish causal relationships. Considering the growth and pubertal changes commonly observed in adolescence, a longitudinal analysis would be useful to better understand these findings. Despite these limitations, this study breaks new ground by seeking to identify the percentage of MRF aggregation among adolescents and the differences in relation to sex, age and socioeconomic status.

\section{Collaborations}

RF Guimarães, MP Silva, O Mazzardo, RV Martins, PI Watanabe and W Campos took part of the conception of the article and the analysis of obtained data, as well as the final writing of the paper. They all agree to the version sent for publishing.

\section{Conclusion}

In summary, the present study observed a high percentage of adolescents classified as overweight and obese, as well as a great number of subjects with limitrophe and altered TC and LDL-c levels, especially among girls. We observed a drop in the percentage of overweight and obese adolescents observed with the increase of age, and higher percentages of altered BP were found among boys. Concerning metabolic variables girls showed higher prevalences at TC and LDL-c, and the percentage of elevated TC classification increased with age. We also pointed out the large percentage of aggregated metabolic risk factors in both sexes, providing evidence that strategies aiming at a reduction in the occurrence of these risk factors are required in this population. Future longitudinal studies are encouraged for the detection of the causality of these factors.

\section{Acknowledgments}

This study was supported by the Physical Education Department, Federal University of Paraná. The authors thank the CAPES and CNPq for financial support. 


\section{References}

1. Eaton DK, Kann L, Kinchen S, Shanklin S, Flint KH, Hawkins J, Harris WA, Lowry R, McManus T, Chyen D, Whittle L, Lim C, Wechsler H; Centers for Disease Control and Prevention (CDC). Youth Risk Behavior Surveillance - United States, 2011. J Sch Health 2012; 61(4):1-162.

2. Santos MG, Pegoraro M, Sandrini F, Macuco EC. Fatores de Risco no Desenvolvimento da Aterosclerose na Infância e Adolescência. Arq Bras Cardiol 2008; 90(4):301-308.

3. Silva MP, Gasparotto GS, Bozza R, Stabelini Neto A, Campos W. Tempo gasto em atividades hipocinéticas relacionado a fatores de risco cardiovascular em adolescentes. Rev Educ Fis 2010; 21(2):279-285.

4. Freedman DS, Goodman A, Contreras OA, DasMahapatra P, Srinivasan SR, Berenson GS. Secular Trends in BMI and Blood Pressure Among Children and Adolescents: The Bogalusa Heart Study. Pediatrics 2012; 130(1):e159-166.

5. Martins RV, Campos W, Bozza R, Barbosa Filho VC, Silva MP. Hypertension and its association with overweight and obesity among adolescents: a school-based survey. Rev Bras Cineantropom Desempenho Hum 2013; 15(5):551-560.

6. Guimarães RF, Silva MP, Mazzardo O, Martins RV, Campos W. Association between sedentary behavior and anthropometric and metabolic profiles among adolescents. Motriz: Rev Educ Fis 2013; 19(4):753-762.

7. Pitangueira JCD, Silva LR, Santana MLP, Monteiro da Silva MC, Farias Costa PR, D’Almeida V, Oliveira Assis AM. Metabolic syndrome and associated factors in children and adolescents of a Brazilian municipality. Nutr Hosp 2014; 29(4):865-872.

8. Dantas MGB, Morais PAO, Silva TFA, Carvalho FO, Schwingel PA. Association Between Indicators of Corporal Adiposity and Cardiovascular Risk Factors Among Brazilian Adolescents. Journal of Exercise Physiology 2013; 16(6):69-78.

9. Christofaro DGD, Fernandes RA, Oliveira AR, Freitas Júnior IF, Barros MV, Ritti-Dias RM. The Association Between Cardiovascular Risk Factors and High Blood Pressure in Adolescents: A School-Based Study. Am J Hum Biol 2014; 26(4):518-522.

10. National High Blood Pressure Education Program Working Group High Blood Pressure in Children and Adolescents: The fourth report on the diagnosis, evaluation, and treatment of high blood pressure in children and adolescents. Pediatrics 2004; 114(2):555-576.

11. Friedewald WT, Levy RI, Fredrickson DS. Estimation of the concentration of low-density lipoprotein cholesterol in plasma, without use of the preparative ultracentrifuge. Clin Chem 1972; 18(6):499-502.

12. Sociedade Brasileira de Cardiologia (SBC). I Diretriz Brasileira de Diagnóstico e Tratamento da Síndrome Metabólica. Arq Bras Cardiol 2005; 84(S1).

13. Tritschler K, Barrow HM, McGee R. Medida e Avaliação em Educação Física e Esportes. Barueri: Manole; 2003.

14. De Onis M, Lobstein T. Defining obesity risk status in the general childhood population: Which cut-offs should we use? Int J Pediatr Obes 2010; 5(6):458-460.
15. Freedman DS, Serdula MK, Srinivasan SR, Berenson GS. Relation of circumferences and skinfold thicknesses to lipid and insulin concentrations in children and adolescents: the Bogalusa Heart Study. Am J Clin Nutr 1999; 69(2):308-317.

16. Associação Brasileira das Empresas De Pesquisa (ABEP): Critério de classificação econômica Brasil. São Paulo: ABEP; 2008.

17. Niehues JR, Gonzales AI, Lemos RR, Bezerra PP, Haas P. Prevalence of Overweight and Obesity in Children and Adolescents from the Age Range of 2 to 19 Years Old in Brazil. Int J Pediatr 2014; 2014:583207.

18. Ng M, Fleming T, Robinson M, Thomson B, Graetz N, Margono C, Mullany EC, Biryukov S, Abbafati C, Abera SF, Abraham JP, Abu-Rmeileh NM, Achoki T, AlBuhairan FS, Alemu ZA, Alfonso R, Ali MK, Ali R, Guzman NA, Ammar W, Anwari P, Banerjee A, Barquera S, Basu S, Bennett DA, Bhutta Z, Blore J, Cabral N, Nonato IC, Chang JC, Chowdhury R, Courville KJ, Criqui MH, Cundiff DK, Dabhadkar KC, Dandona L, Davis A, Dayama A, Dharmaratne SD, Ding EL, Durrani AM, Esteghamati A, Farzadfar F, Fay DF, Feigin VL32, Flaxman A, Forouzanfar MH, Goto A, Green MA, Gupta R, Hafezi-Nejad N, Hankey GJ, Harewood HC, Havmoeller R, Hay S, Hernandez L, Husseini A, Idrisov BT, Ikeda N, Islami F, Jahangir E, Jassal SK, Jee SH, Jeffreys M, Jonas JB, Kabagambe EK, Khalifa SE, Kengne AP, Khader YS, Khang YH, Kim D, Kimokoti RW, Kinge JM, Kokubo Y, Kosen S, Kwan G, Lai T, Leinsalu M, Li Y, Liang X, Liu S, Logroscino G, Lotufo PA, Lu Y, Ma J, Mainoo NK65, Mensah GA, Merriman TR, Mokdad AH, Moschandreas J, Naghavi M, Naheed A, Nand D, Narayan KM, Nelson EL, Neuhouser ML, Nisar MI, Ohkubo T, Oti SO, Pedroza A, Prabhakaran D, Roy N, Sampson U, Seo H, Sepanlou SG, Shibuya K, Shiri R, Shiue I, Singh GM, Singh JA, Skirbekk V, Stapelberg NJ, Sturua L, Sykes BL, Tobias M, Tran BX, Trasande L, Toyoshima H, van de Vijver S, Vasankari TJ, Veerman JL, Velasquez-Melendez G, Vlassov VV, Vollset SE, Vos T, Wang C, Wang X, Weiderpass E, Werdecker A, Wright JL, Yang YC, Yatsuya H, Yoon J, Yoon SJ, Zhao Y, Zhou M, Zhu S, Lopez AD, Murray CJ, Gakidou E. Global, regional, and national prevalence of overweight and obesity in children and adults during 1980-2013: a systematic analysis for the Global Burden of Disease Study 2013. The Lancet 2014; 384(9945):766-781.

19. Morais NS, Miranda VPN, Priore, SE. Body image of female adolescents according body composition and sedentary behavior. Cien Saude Colet 2016; 23(8):26932703.

20. Moraes ACF, Falcão MC. Lifestyle factors and socioeconomic variables associated with abdominal obesity in Brazilian adolescents. Ann Hum Biol 2013; 40(1):1-8.

21. Jessup A,Harrell JS. The Metabolic Syndrome: Look for It in Children and Adolescents, Too! Clin Diabetes 2005; 23(1):26-32.

22. Drižienė Z, Jakutienè E, Stakišaitis D, Pundziene B, Sveikata A. Characteristics of gender-related circadian arterial blood pressure in healthy adolescents. Medicina (Kaunas) 2008; 44(10):768-744 
23. Stozicky F, Slaby P, Volenikov L. Longitudinal study of serum cholesterol, lipoproteins and sex hormones during puberty. Acta Paediatr Scand 1991; 80(12):11391144.

24. Frohnert BI, Jacobs Junior DR, Steinberger J, Moran A, Steffen LM, Sinaiko AR. Relation Between Serum Free Fatty Acids and Adiposity, Insulin Resistance, and Cardiovascular Risk Factors From Adolescence to Adulthood. Diabetes 2013; 62(9):3163-3169.

25. Courtney JJ, Ian J. Distribution of Lipoproteins by Age and Gender in Adolescents. Circulation 2006; 114(10):1056-1062.

26. Dai S, Steffen M, Mihalopoulos N, Labarthe DR. Blood Lipids in Children: Age-Related Patterns and Association with Body-Fat Indices, Project Heartbeat! Am J Prev Med 2009; 37(1):S56-S64.

27. Okosun IS, Boltri JM, Lyn R, Davis-Smith M. Continuous metabolic syndrome risk score, body mass index percentile, and leisure time physical activity in American children. J Clin Hypertens (Greenwich) 2010; 12(8):636-644.

28. Nunes HEG, Gonçalves ECA, Vieira JAJ, Silva DAS. Clustering of Risk Factors for Non-Communicable Diseases among Adolescents from Southern Brazil. PLoS ONE 2016; 11(7):e0159037.

29. Berenson GS, Srnivasan SR. Cardiovascular risk factors in youth with implications for aging: The Bogalusa Heart Study. Neurobiol Aging 2005; 26(3):303-307.

30. Expert Panel on Integrated Guidelines for Cardiovascular Health and Risk Reduction in Children and Adolescents; National Heart, Lung, and Blood Institute. Expert panel on integrated guidelines for cardiovascular health and risk reduction in children and adolescents. Pediatrics 2011; 128(Supl. 5):S213-S256.

Artigo apresentado em 06/07/2016

Aprovado em 02/07/2017

Versão final apresentada em 04/07/2017 